\title{
䅡椎後縦勒带骨化症女性患者の骨折の頻度について
}

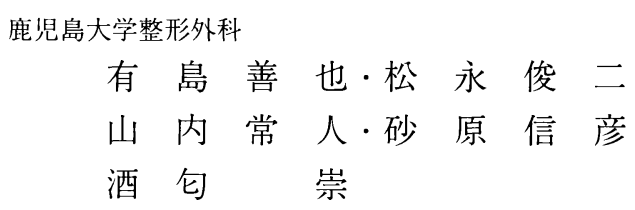

\section{Incidence of Fracture in Women with Ossification of the Posterior Longitudinal Ligament}

\author{
Yoshiya Arishima, Shunji Matsunaga, Tsuneto Yamauchi, \\ Nobuhiko Sunahara and Takashi Sakou \\ Department of Orthopaedic Surgery, \\ Faculty of Medicine, Kagoshima University, Kagoshima, Japan.
}

In order to clarify the low frequency of fractures in patients with ossification of the posterior longitudinal ligament (OPLL), the incidence of the fractures in women whit OPLL of the cervical spine was compared with that in women without OPLL.

69 women with OPLL and 94 women without OPLL (control) were used for the study. The ages of the patient with OPLL ranged from 52 to 86 years old and averaged 70.1 years old, whie the ages of the women without OPLL ranged from 60 to 75 years old and averaged 68 years old. For these women, we surveyed the past history of the fractures of spine, hip or distal forearm. In some of these women, bone mineral density (BMD) were measured using dual energy X-ray absorptiometry (DEXA).

In the OPLL group, only 8 patients $(11.6 \%)$ had fractures wheras in the ccontrol group, 23 women $(24.5 \%)$ had fractures. There was a significant difference $(p<0.05)$ between these two groups. BMD of the lumbar spine in the OPLL group was higher than that of the control group. tients.

In conclusion, there was a tendency for a low frequency of fractures in OPLL pa-

Key words : OPLL (後縦勒帯骨化症), incidence of fracture (骨折発生率), BMD (骨塩量), osteoporosis（骨粗鬆症）

$$
\text { はじめに }
$$

頚椎後縦勒帯骨化症（以下 OPLL）の成因は未だ 不明であるが，本症の発症に全身的骨化因子が関与寸 ることが報告されている。近年骨密度測定により， OPLL 患者において加齢に伴う骨密度の減少が少な いことが報告されているが，OPLL 患者における骨 折の発生頻度に関する文献は少ない. そこで, OPLL 女性患者に扔ける骨折の発生頻度, および骨折密度に
ついて調査し，健常人との比較を行った.

\section{対象と方法}

対象として OPLL 郡は, 鹿児島大学整形外科で経 過観察中の女性 OPLL 患者 69 名 (年齢 52 86 歳, 平 均 70.1 歳）とした。骨化型別内訳は, 分節型 35 名, 連続型 20 名, 混合型 12 名, その他型 2 名であった。 対照群は, 鹿児島県在住の非 OPLL 女性 94 名（年齢 60〜75 歳, 平均 68 歳）とした。これらに対し脊椎圧 


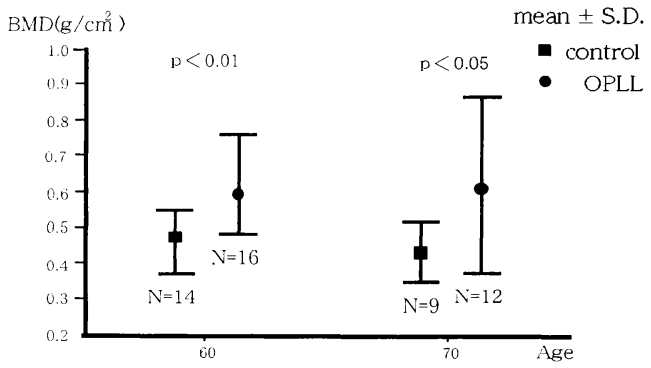

図 1 OPLL 群と対照群の骨密度の比較

迫骨折，大腿骨䅡部骨折および前腕骨遠位端骨折の 3 骨折について，その既往の有無を調查した。

また骨密度測定は OPLL 群 28 名, 対照群 23 名に 対して, HOLOGIC 社製 QDR-2000を使用し第 3 腰 椎側面にて行った.

\section{結果}

OPLL 群では 69 名中 8 名 $(11.6 \%)$ にしか骨折の 既往を認めなかったが, 対照群では 94 名中 23 名 (24.5\%) に骨折の既往を認め, OPLL 群において有 意に低かった。

骨折部位別では, OPLL 群では脊椎圧迫骨折 4 例, 大腿骨澒部骨折 2 例, 前腕骨遠位端骨折 4 例で, 春椎 压迫骨折および前腕遠位端骨折がやや多く, 大腿骨頚 部骨折が少なかったが, 対照群においても脊椎圧迫骨 折 12 例, 大腿骨澒部骨折 5 例, 前腕骨遠位端骨折 8 例と，ほぼ同数の傾向にあった。

OPLL 群に関して骨化型別にみると, 分節型では 35 名中 5 名 $(14 \%)$ と最も頻度が高く, 一方, 連続 型では 20 名中 0 名 $(0 \%)$, 混合型では 12 名中 1 名 (8％) と,ともに低い傾向にあった。 その他型は症例 が少なく 2 名中 2 名ともに骨折に既往があった.

骨密度は 60 代, 70 代においてOPLL 群で有意に増 加していた（図 1).

\section{考察}

健常人における脊椎圧迫骨折, 大腿骨澒部骨折, 前 腕骨遠位端骨折の発生頻度については, Meltom ら
が 50 歳以上のアメリカ在住白人女性において合計 $39.7 \%$ であったと報告している゙!。対照群の鹿児島県 在住の非 OPLL 女性の骨折発生頻度は $24.5 \%$ であり， OPLL 群の $11.6 \%$ と比較すると，OPLL 群において 有意に低かった。この結果から，OPLL 女性患者で は健常人に比べて加齢に伴う骨粗繁化による骨折は少 ないことが示唆された。

従来より，OPLL患者の全身的骨化素因を解明す る手段として身体各部位の骨密度測定が行われてき た ${ }^{1-3)}$. 最近では Dual energy X-ray absorptiometry（DEXA）を用いた骨密度測定により， OPLL 患者の骨密度は健常人に比べて増加すること が指摘されている年文，今回の結果でも OPLL 群の骨 密度は対照群と比べて有意に高く，これらを指示する ものであった。

以上より，OPLL 患者においては勒帯のみならず， 全身的に骨化因子が関与する可能性が示唆された。

$$
\text { ま と め }
$$

(1) OPLL 女性患者 69 名中 8 名 $(11.6 \%$ ) に骨折 の既往が認められ，対照群 $(24.5 \%)$ に比べて有意に 低かった。

(2) 骨化型別では，分節型に多く，連続型および混 合型に少ない傾向にあった。

\section{参 考 文 献}

1）星野勇一ほか：脊柱勒帯骨化症におけるカルシウム代 謝について, 日整会誌, $56: 1072-1074,1982$.

2)市本裕康ほか：頚椎 OPLL 症例における骨塩量の検討. 厚生省特定疾患脊椎勒帯骨化症調査研究班平成元年度研 究報告書, 141-142, 1990.

3）川上俊文ほか：脊柱勒帯骨化症の骨塩量, 中部整災誌, $26: 1269-1271,1983$

4）侭田敏且ほか：澒椎後縦勒帯骨化症患者の全身各部位 の骨密度と年齢との関係, 厚生省特定疾患脊椎勒帯骨化 症調査研究班平成 4 年度研究報告書, 13-17, 1993 .

5) Melton LJ III et al: How many women have osteoporosis? J Bone Miner Res, 7 : 1005-1010, 1992.

6）酒匂 崇ほか：澒椎後縦勒帯骨化症の DXA 法による 骨量の検討, 厚生省特定疾患脊椎勒帯化症調查研究班平 成 5 年度研究報告書, $12-13,1994$. 